\title{
BOGUMIŁ GASEK
}

Uniwersytet Wrocławski, Polska

b.gasek@wp.pl

\section{Polisemia jako problem w rosyjsko-polskiej leksykografii przekładowej}

Wielki słownik dwujęzyczny należy do podstawowych narzędzi w pracy tłumacza, nauczyciela języka obcego, studenta neofilologii, a więc każdego, kto ze względu na to, że relacje między dwoma językami są atrybutem jego profesji, potrzebuje dużego, rzetelnego opracowania, w którym może odnaleźć ekwiwalenty potrzebnych słów i zwrotów oraz upewnić się co do poprawności stosowanych przez siebie odpowiedników bądź też wyborów translatorskich dokonanych przez autorów studiowanej literatury, czytanych artykułów i oglądanych filmów. Wielki słownik dwujęzyczny jest zatem ilustracją aktualnych międzyjęzykowych relacji przekładowych, wynikłych także z dokonań poprzednich pokoleń leksykografów, gdyż każde kolejne dzieło leksykograficzne to krytyczna kontynuacja dokonań poprzedników. Autorzy nowego słownika dwujęzycznego nie zaczynają przecież swej pracy od zera - punktem wyjścia są też odpowiedniki notowane w uprzednio wydanych słownikach. W nowych słownikach dochodzi do rewizji wcześniej zastosowanych rozwiązań, lecz pewne ekwiwalenty pozostają bez zmian, choćby z uwagi na to - jak pisał Jan Wawrzyńczyk — „,n]ie sposób translandowi шоколад przypisać inny translat niż: czekolada, аптека — apteka, вода — woda itd.; one muszą przechodzić ze słowników starszych do nowych"1.

Wielki słownik dwujęzyczny nazywany bywa słownikiem przekładowym $\mathrm{z}$ racji swego adresata. W węższym jednak znaczeniu to specjalny słownik przeznaczony do tłumaczenia tekstów, a więc zawierający nie tylko innojęzyczne odpowiedniki, lecz także algorytm działania umożliwiający tworzenie nowych ekwiwalentów w zależności od konkretnych potrzeb. W takim słowniku oprócz ekwiwalentów stosuje się rozbudowany system uwag, kwalifikatorów i komentarzy, aby zapewnić możliwość poprawnego tłumaczenia.

1 J. Wawrzyńczyk, Blaski i cienie translatosfery, [w:] Na tropach translatów. W poszukiwaniu odpowiedników przekładowych, red. W. Chlebda, Opole 2011, s. 170. 
W polskiej rusycystyce długo czekano na nowy „,wielki” słownik po wydawanym od 1970 roku Wielkim stowniku rosyjsko-polskim ${ }^{2}$. Koncepcja zapowiadanego jako pisanego od nowa Słownika Państwowego Wydawnictwa Naukowego (dalej: słownik PWN $)^{3}$ kształtowała się między innymi w procesie krytycznej analizy ${ }^{4}$ dwóch słowników Wiedzy Powszechnej (i ich kolejnych uzupełnionych wydań): Wielkiego stownika polsko-rosyjskiego ${ }^{5}$ i wspominanego Wielkiego stownika rosyjsko-polskiego oraz Ilustrowanego stownika rosyjsko-polskiego i polsko-rosyjskiego ${ }^{6}$. Wydany w roku 2004 również w wersji elektronicznej słownik PWN to nowy i zarazem nowatorski, bo będący wynikiem wieloletnich prac części jego autorów $^{7}$ w nurcie „konstruktywnej krytyki leksykograficznej”, , słownik przekładowy ${ }^{9}$. Uzasadnia to wybór wspomnianego słownika jako przedmiotu analizy jednego z istotnych i skomplikowanych zjawisk w praktyce leksykograficznej i działalności translatorycznej, jakim jest polisemia.

2 A. Mirowicz et al., Wielki stownik rosyjsko-polski, t. 1-2, wyd. 6, Moskwa-Warszawa 1999.

3 Wielki słownik rosyjsko-polski z kluczem polsko-rosyjskim, red. J. Wawrzyńczyk, Warszawa 2004.

4 Znalazła ona swój wyraz m.in. w następujących publikacjach: H. Bartwicka, Krytycznie o sposobie prezentacji leksyki potocznej w Wielkim słowniku polsko-rosyjskim, [w:] Wspótczesny język polski i rosyjski. Konfrontacja przekładowa, red. A. Bogusławski, J. Mędelska, Warszawa 1997, s. 127-145; H. Bartwicka, J. Mędelska, J. Wawrzyńczyk, Glosy do Wielkiego słownika polsko-rosyjskiego Dymitra Hessena i Ryszarda Stypuły, Bydgoszcz 1983; J. Wawrzyńczyk, O thumaczeniu przymiotników w Wielkim słowniku polsko-rosyjskim, „Przegląd Rusycystyczny”, 1983, nr 2, s. 37-44; idem, Aktualne problemy leksykografii polsko-rosyjskiej (Część I), „Przegląd Rusycystyczny" 1984, nr 3, s. 83-97; idem, Aktualne problemy leksykografii polsko-rosyjskiej (Część II), „Przegląd Rusycystyczny” 1984, nr 4, s. 5-14; idem, Język rosyjski w stownikach polsko-rosyjskich powojennego czterdziestolecia, [w:] Z aktualnych studiów rusycystycznych. Językoznawstwo i glottodydaktyka, Olsztyn 1987, s. 163-171; idem, O rozwoju leksykografii rosyjsko-polskiej, „Przegląd Rusycystyczny" 1992, nr 3-4, s. 53-63; idem, Wyrazy i zwroty zwiąane z życiem religijnym w ,wielkiej” leksykografii rosyjsko-polskiej, „Acta Polono-Ruthenica” 1997, t. 2, s. 315-322.

5 D. Hessen, R. Stypuła, Wielki stownik polsko-rosyjski, t. 1-2, wyd. 5, Warszawa 1998.

6 J. Wawrzyńczyk, Nowoczesność w polsko-rosyjskiej leksykografii przekładowej (Uwagi o pracy: A. Bogusławski, Ilustrowany słownik rosyjsko-polski i polsko-rosyjski, Warszawa 1978, ss. 1179, „Przegląd Humanistyczny” 1980, nr 4, s. 187-193.

7 Jan Wawrzyńczyk pisze w odniesieniu do dwóch wielkich słowników (rosyjsko-polskiego i polsko-rosyjskiego) pod swoją redakcją, że: „Świadomie polemiczne konkretne nawiązania i rozwiązania strukturalno-leksykograficzne mają precedens w polskiej leksykografii dwujęzycznej" — J. Wawrzyńczyk, Blaski..., s. 171.

${ }^{8}$ O krytyce leksykograficznej i o pojęciu konstruktywnej krytyki leksykograficznej więcej pisze Margarita Czernyszowa, М.И. Чернышева, Параметры лексикографической критики, [w:] Слово и словарь. Vocabulum et vocabularium. Сборник научных трудов по лексикографии, wyd. 12, Charkow-Klagenfurt 2011, s. 7-10.

9 We „Wstępie” do słownika PWN znajdujemy stwierdzenia, które wskazują, że autorzy traktują swoje dzieło jako słownik przekładowy: „Unikamy podawania w słowniku informacji zbędnych, m.in. gramatycznych, nie zapobiegających tym błędom, nieprzydatnych w samym procesie przekładu z rosyjskiego na polski (słownik przekładowy nie powinien przejmować funkcji słownika jednojęzycznego); zaoszczędzone miejsce przeznaczamy na rozbudowę siatki haseł” (s. 7). 
Polisemia (wieloznaczność) definiowana jako „[p]osiadanie przez wyrażenie jęz. (morfem, wyraz, zwrot lub zdanie) kilku znaczeń"10 przysparza określone trudności w pracy leksykografa. Powstaje problem rozróżnienia polisemii i homonimii, gdzie wpływ na układ hasła mają jednojęzyczne (objaśniające) słowniki języka wyjściowego. Poza nawias niniejszych rozważań wyłączam kwestię uznania konkretnego leksemu za polisem lub homonim. W dużej bowiem mierze uwarunkowana jest ona wskazaniami słowników definicyjnych, z których korzystają leksykografowie przekładowi ${ }^{11}$.

Kolejny problem to zakres polisemii uwzględnianej w słowniku. Powstaje pytanie, czy ograniczyć się wyłącznie do polisemów podanych przez wyjściowy słownik (słowniki) objaśniający czy też w określonych przypadkach włączać do hasła dalsze znaczenia: potoczne, żargonowe, wulgarne, przestarzałe, gminne, terminologiczne i inne. Przyjęcie jakiegoś założenia umożliwia określenie uwzględnianych znaczeń konkretnych polisemów, a następnie rozpoczęcie procesu ekwiwalentyzacji. W dalszej części artykułu spróbuję dokonać analizy rozwiązań przyjętych w Słowniku PWN, wykorzystując w charakterze ilustracji wybrane reprezentatywne przykłady, a następnie sformułować wnioski dotyczące prezentacji polisemii w słowniku przekładowym nowego typu.

Autorzy słownika w liczącym dziewięć stron „Wstępie” aż czterokrotnie uzasadniają stosowanie różnych rozwiązań oszczędnością miejsca, co może świadczyć o tym, że zasada ekonomicznego podawania informacji jest jednym $\mathrm{z}$ istotnych założeń przyjętych przy konstruowaniu tego dzieła ${ }^{12}$.

Przejawem zasady redukcji informacji zbędnych jest następujące założenie:

Brak wskazówki interpretacyjnej oznacza, że różne sytuacje użycia obsługiwane przez wyraz rosyjski pokrywają się z sytuacjami, w których poprawne będzie użycie odpowiedniego polskiego wyrazu czy wyrażenia przytoczonego w danym artykule (por. np. artykuł бoa boa, gdzie nie ma żadnej pomocniczej informacji, ponieważ zarówno rosyjski wyraz, jak i jego polski odpowiednik może być użyty czy to na oznaczenie węża, czy to szala) ${ }^{13}$.

10 K. Polański, Polisemia, [w:] Encyklopedia językoznawstwa ogólnego, red. K. Polański, wyd. 2, Wrocław 1999, s. 447.

${ }^{11}$ Należy jednak odnotować, że pewne rozwiązania na tym polu doczekały się krytyki, np. Katarzyna Wojan, pisząc o słowniku PWN, zauważa, że: „niektóre polisemy uznane zostały za homonimy, np. соня »koszatka«, соня »śpioch«, сыч»sowa« сы »»odludek«, mun »typ (kategoria, rodzaj), i mun »facet, gość«, типаж »charakterystyka, specyfika«, i типаж »typ (np. komediowy«), тюфяк 1. »materac«, 2. »siennik« тюфяк »fajtłapa, niedojda« itd. (K. Wojan, Wstep do badań wieloznaczności leksemów w ujęciu kontrastywnym, Gdańsk 2010, s. 83.). Z drugiej strony autorka odnotowuje, że: „Mimo swych niedostatków słownik ten jest także nowatorski — uwypukla homonimiczność nazw własnych" (ibidem).

12 Jako ilustrację przytoczę jeden tylko cytat: „Określone grupy słownictwa, których nie zalicza się do rzadkiego, wąskospecjalistycznego, zostały wykluczone z siatki haseł ze względów oszczędnościowych" - Wstęp, [w:] Wielki słownik rosyjsko-polski z kluczem polsko-rosyjskim, red. J. Wawrzyńczyk, Warszawa 2004, s. 8.

13 Ibidem, s. 14. 
Powyższa zasada budzi poważne zastrzeżenia teoretyczne i praktyczne. Przede wszystkim rzadką sytuacją jest całkowite pokrywanie się wszystkich znaczeń jednostek polisemicznych w dwóch językach. Prawidłowa interpretacja znaczeń rosyjskiego translandu wymaga znajomości wszystkich znaczeń translatu, co podważa zasadność traktowania słownika jako dyferencyjnego ${ }^{14}$, stawiając w trudniejszej sytuacji rodzimych użytkowników języka rosyjskiego. Zaufanie odbiorcy może zostać wystawione na próbę już przy pierwszych przypadkach niedokładności.

Porównajmy:

штанга [-ги] sztanga

Uniwersalny stownik języka polskiego (USJP) ${ }^{15}$ podaje tylko dwa znaczenia tego leksemu:

sztanga 〈niem. Stange〉

1. sport. «metalowy pręt, na którego oba końce zakłada się pierścienie różnej wagi, niezbędny do uprawiania podnoszenia ciężarów»:

Źle chwycił sztangę w pierwszym podejściu rwania.

2. techn. «metalowy pręt; sztaba»

- Sztanga chroniąca szybę wystawową.

Natomiast w słowniku języka rosyjskiego pod redakcją Kuzniecowa (SK) ${ }^{16}$ znajdziemy:

1. Сnеu. Металлический стержень, используемый как деталь во многих механизмах. Буровая ш.

2. Боковая стойка (иногда и верхняя перекладина) футбольных, хоккейных и т.п. ворот. Мяч попал в шттангу.

3. Снаряд для занятий тяжёлой атлетикой, состоящий из металлического стержня, на концах которого укреплены съёмные диски различного веса.

口 Шта́нговый, -ая, -ое. Спец̧. (1 зн.). Ш-ое крепление. Ш-ое бурение.

Zestawiając znaczenia słownikowe obydwóch leksemów, widzimy, że relacja ekwiwalencji obejmuje tylko jedno z nich. Wobec braku dodatkowych wskazówek w słowniku PWN jego odbiorca ma prawo zastanawiać się, czy a) relacja штанга-sztanga dotyczy tylko jednego znaczenia (którego?), dwóch, czy może jednak trzech? Tę ostatnią ewentualność wykluczy native speaker języka polskiego, który dokładnie zapoznał się z zasadami konstrukcji i użycia słownika PWN, i wie, iż kluczem do wyodrębnienia znaczeń rosyjskiego polisemu, jest jego polski odpowiednik (sic!). Wobec powyższego można stwierdzić brak ekwiwalentyzacji drugiego znaczenia rosyjskiego leksemu, w którym w dodatku zachodzi

14 Ze „Wstępu” do słownika PWN wynika, że jest on przeznaczony „zarówno dla Polaków uczących się języka rosyjskiego, jak i dla Rosjan uczących się języka polskiego”-ibidem, s. 11.

15 Uniwersalny słownik języka polskiego, red. S. Dubisz, Warszawa 2003, CD-ROM.

16 Новейший большой толковый словарь русского языка, red. С.А. Кузнецова, Sankt-Petersburg 2008. 
w stosunku do języka polskiego relacja „niedyferencjacji znaczeń" ${ }^{\text {, }}$, w związku z czym jest to zarówno słupek bramki, jak i jej poprzeczka.

Zjawisko „niedyferencjacji znaczeń” w stosunku do języka polskiego nie zostało wzięte pod uwagę również w innych hasłach, np.:

певица [-цы] śpiewaczka

Rosyjskie słowo oznacza „kobietę zajmującą się zawodowo śpiewaniem”, ale w odróżnieniu od języka polskiego — zarówno w operze, jak i na estradzie, co w języku polskim obsługują dwa różne leksemy - śpiewaczka i piosenkarka. Te dwa różne ekwiwalenty są niezbędne do prawidłowego zrozumienia leksemu wyjściowego i przekładu tekstów leksem ten zawierających. Gdyby autorzy słownika nie dążyli do oszczędności miejsca za wszelką cenę, zapewne w haśle pojawiłyby się typowe przykłady użycia (i łączliwości zarazem) np. „оперная певица”, „эстрадная певица”, wymuszając podanie obydwóch ekwiwalentów polskich.

$\mathrm{Z}$ jeszcze inną sytuacją mamy do czynienia w poniższym haśle:

гайка [гайки; род. мн. гаек] nakrętka

Jako drugie znaczenie wyrazu nakrętka WSJP ${ }^{18}$ podaje „rodzaj pokrywki z gwintem wewnętrznym, służącej do szczelnego zamykania naczyń”. Również na drugim miejscu takie znaczenie notuje USJP. Nawet jeśli nie jest to znaczenie podstawowe polskiego wyrazu ${ }^{19}$, to niewątpliwie przychodzi ono na myśl natywnemu użytkownikowi polszczyzny przy bezkontekstowym przywołaniu tej jednostki leksykalnej. Rosyjski leksem takiego znaczenia nie ma.

Dany sposób prezentacji materiału, a więc podawanie haseł bez kwalifikatorów, uwag nawiasowych, przykładów użycia i wyszczególnienia znaczeń nawet nie poważnie upraszcza rzeczywiste relacje międzyjęzykowe, ale wręcz je deformuje. Podobnych przykładów w słowniku jest więcej:

блин [-на] blin

ботаник [-ка] botanik

17 To zjawisko Leonid Barchudarow definiował w następujący sposób: „одному слову какого-либо языка, выражающему более широкое («недифференцированное») понятие, то есть обозначающему более широкий класс денотатов, в другом языке могут соответствовать два или несколько слов, каждое из которых выражает более узкое, дифференцированное, сравнительно с первым языком, понятие, то есть относится к более ограниченному классу денотатов. Так, в русском языке существует слово рука, которому в английском соответствуют два слова - arm и hand, каждое из которых обозначает более узкое понятие: arm обозначает верхнюю конечность от плеча до кисти, a hand - кисть руки, в то время как русское рука обозначает всю верхнюю конечность человека от плеча до кончиков пальцев" - Л.С. Бархударов, Язык и перевод (Вопросы общей и частной теории перевода), Moskwa 1975, s. 77.

18 Współczesny słownik języka polskiego, red. B. Dunaj, Warszawa 1999, t. 1-2.

19 Na temat podstawowego znaczenia słowa precyzyjnie wypowiedział się wiele lat temu Ruben Budagow: „Что же касается основного значения слова, то, как было замечено еще Паулем, - это наименее обусловленное контекстом значение, приходящее на ум в первую очередь, когда возникает вопрос о данном слове" - Р.А. Будагов, Сравнительно-семасиологические исследования (романские языки), Moskwa 1963, s. 17. 


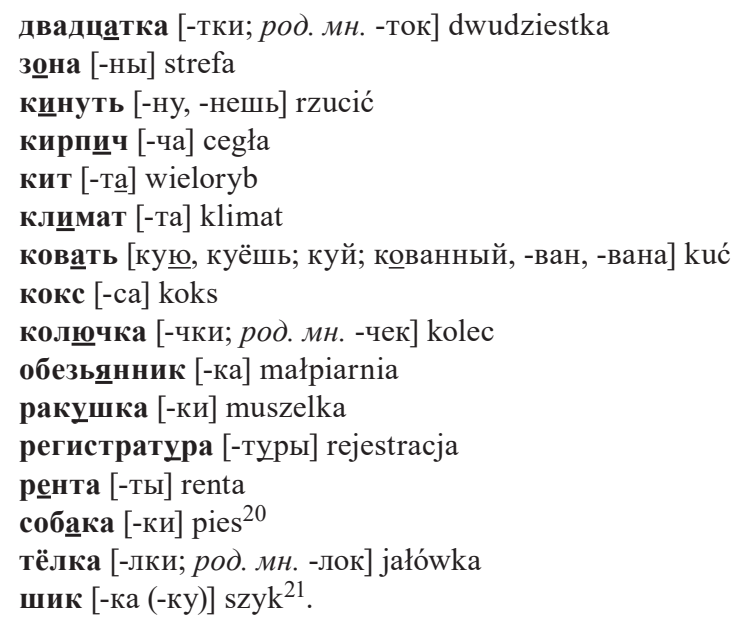

Przytoczone przykłady w zestawieniu z twierdzeniami teoretycznymi pozwalają na sformułowanie trzech wniosków. Nie da się obronić koncepcji ekwiwalentów 1:1 bez kwalifikatorów, komentarza, czy przykładu użycia. Autorzy są niekonsekwentni w stosowaniu zabiegów „różnicujących” znaczenia. Nie sposób ustalić, gdzie mamy do czynienia z niekonsekwencją, a gdzie z niedopatrzeniem, czy jawnym błędem. Porównajmy:

кинуть [-ну, -нешь] rzucić

Nie można jednoznacznie stwierdzić, czy autorzy świadomie ignorują znaczenie potoczne leksemu ${ }^{22}$ (a jeśli tak, to dlaczego?), nie wiedzą o jego istnieniu czy też przypisują takie znaczenie leksemowi polskiemu. Analiza słownika przekład-

20 Oddzielnego komentarza wymaga brak jakiejkolwiek ilustracji użycia. Najkorzystniejsze byłoby włączanie do takich haseł różnego rodzaju frazemów, które tworzyłyby dodatkowo w każdym haśle sieć rosyjsko-polskich par przekładowych. Tego typu ilustracji (nawet pojedynczych) wymagają prawie wszystkie hasła o relacji jeden do jednego. W danym artykule hasłowym powinny się znaleźć m.in. takie frazemy jak собаку съесть, спустить собак, вешать собак, бешеная собака. Szerzej o problematyce frazematyki w słowniku przekładowym - zob. B. Gasek, Odtwarzalne wielowyrazowce w rosyjsko-polskiej leksykografii przektadowej, [w:] Stowo, tekst, czas 12: frazeologia w idiolekcie i systemach języków słowiańskich : w 200. rocznicę urodzin Tarasa Szewczenki, t. 1, red. M. Aleksiejenko et al., Szczecin-Greifswald 2014, s. 244-253.

${ }^{21}$ Prawie wszystkie wymienione translandy i translaty są jednostkami polisemicznymi, których znaczenia nie pokrywają się w pełni, tworząc swoistą siatkę znaczeń, np. rosyjskie собака oznacza znak@, a więc małpę, a polskie pies to również żargonowe określenie policjanta. Co ciekawe, ze słownika dowiemy się o istnieniu relacji przekładowej собачка — małpa: „собачка [-чки; род. мн. -чек]

1. piesek

2. (в оружии) spust

3. (приспособление, препятствующее обратному движению чего-либо) zapadka

4. (знак@) małpa", chociaż w takim znaczeniu słowo собачка występuje raczej marginalnie. Symbol graficzny@w ruszczyźnie jest obsługiwany przede wszystkim przez leksem собака.

22 кинуть - potocznie oszukać. 
owego może być niewystarczająca do prawidłowego wyboru ekwiwalentu, gdyż znaczenia leksemu wyjściowego notowane są z punktu widzenia opisywanego języka, a nie relacji międzyjęzykowych. Na kształt tych ostatnich wpływ mogą mieć zjawiska „niedyferencjacji znaczeń” oraz enantiosemii ${ }^{23}$. Potwierdzeniem (przynajmniej częściowym) jest układ hasła:

мантия [-тии] (одежда в виде плащуа, напр. королевская, кардинальская) płaszcz

W nawiasie widzimy przeniesienie sedna definicji słownikowej24, co nie pozwala dostrzec, że w niektórych użyciach poprawnym odpowiednikiem leksemu wyjściowego jest pol. toga.

Niekiedy ignorowane jest znacznie pragmatyczne leksemu wyjściowego, np.:

соучастник [-ка] wspólnik

W języku rosyjskim to prawie zawsze współuczestnik jakiegoś nielegalnego, negatywnego przedsięwzięcia, najczęściej po prostu przestępstwa. Potwierdza to lektura definicji słownika objaśniającego — według SK сооучастник to: „,[т]от, кто участвует или участвовал вместе с кем-л. в совершении чего-л. (чаще неблаговидного, дурного)", co zostaje dodatkowo potwierdzone przykładami użycia: „С. преступления. С. в преступлении”. Te ostatnie powinny trafić do słownika przekładowego, mając walor ilustracji standardowego użycia, lecz także dodatkowej informacji o rzeczywistym znaczeniu jednostki rosyjskiej. Wskazana byłaby też uwaga nawiasowa o znaczeniu pragmatycznym translandu. Co ciekawe, tego typu uwagą został opatrzony synonim przytoczonej jednostki, co wskazuje to na niekonsekwencję i przypadkowość stosowania wskazówek interpretacyjnych. Porównajmy:

собщник [-ка] wspólnik (wspótuczestnik przestępstwa) oraz сорбщница [-цы] wspólniczka (współuczestnik przestępstwa).

Struktura jeden do jednego przeczy podstawowej wiedzy językoznawczej o polisemii — $\mathrm{w}$ języku więcej jest znaczeń niż słów, a poza użyciem terminologicznym jednostki monosemiczne są raczej wyjątkiem niż regułą, pełna odpowiedniość polisemów dwóch języków występuje bardzo rzadko. Reasumując, twierdzę że hasła o relacji jeden do jednego powinny trafiać do wielkiego słownika przekładowego na zasadzie wyjątku. Nawet w przypadkach, w których naturalnym

23 Jak podaje Katarzyna Wojan „zjawisko enantiosemii polega na współwystępowaniu (kumulacji) w jednym leksemie dwu przeciwstawnych (ambiwalentnych) treści” — K. Wojan, Rosyjskie leksemy homonimiczne w teorii językoznawczej i praktyce leksykograficznej, Gdańsk 2011, s. 116-17.

24 Na przykład SK podaje: „1. Широкая, длинная (до пят) одежда в виде плаща, надеваемая поверх другой одежды. Монашеская м. Чёрная м. Завернуться в мантию. Приподнять мантию”. Dwa pozostałe znaczenia nie zostały w ogóle uwzględnione: „2. Зоол. Складка кожи у некоторых беспозвоночных животных, охватывающая тело. М. медузы. 3. Геол. Внутренняя сфера Земли, представляющая собой оболочку, расположенную между земной корой и ядром. М. Земли. Исследование процессов в земной мантии". 
wydaje się jednostkowy ekwiwalent, powinny znaleźć się ilustracje jego użycia. Trudno zaprzeczyć, że polskim odpowiednikiem ros. кит jest wieloryb, ale już киты наџки to filary nauki, czego użytkownik powinien dowiedzieć bezpośrednio ze słownika. Co ciekawe, podobną relację do przytoczonej autorzy słownika PWN dostrzegli dla leksemu зубр, konstruując trzypunktowy odpowiednik:

зубр [-pa]

1. żubr

2. (консервативно настроенный человек) zacofaniec / wstecznik

3. (иенный специалист) spec / fachman

To hasło zostało przygotowane solidnie, ale pokazuje równocześnie niekonsekwencję w opracowaniu słownika.

Obok nagannej, właściwej słownikom kieszonkowej maniery podawania „gołych" ekwiwalentów (często — jak w przykładach powyżej — ze względu na ignorowanie polisemii - ekwiwalentów wątpliwych), można dostrzec artykuły hasłowe, w których wskazuje się na specyfikę i ograniczenia użycia ekwiwalentu. W tym celu zastosowano kilka metod:

1) волк [-ка; -ки, -коㅡ] wilk (nie pies)

Nawiasowe przeczenie jest prostą i skuteczną metodą zawężenia znaczenia leksemu wyjściowego. Zapewne jednak mogłoby być stosowane częściej (np. w przytaczanym już haśle гайка) i w połączeniu z innymi informacjami i instrukcjami o tworzeniu i użyciu odpowiednika przekładowego (z hasła волк nie dowiemy się niczego o znaczeniu konotacyjnym i typowych użyciach metaforycznych translandu i translatu. Brakuje co najmniej połączeń морской волк; степной волк; матёрый волк. W słowniku tworzonym rzeczywiście z myślą о tłumaczu nastąpiłaby próba ekwiwalentyzacji frazemów тамбовский волк тебе товарищ; волка ноги кормят; хоть вллком вой.

2) Nawiasowe ograniczenie zakresu łączliwości leksemu wyjściowego. Metoda może być atrakcyjna ze względu na swoją prostotę i przejrzystość, jednak w przykładzie poniżej została zastosowana nieprezyzyjnie.

трейлер [-pa] przyczepa (samochodowa, kempingowa)

Трейлер to z jednej strony przyczepa kempingowa, z drugiej specjalny rodzaj przyczepy do samochodów ciężarowych, służącej do przewozu pojazdów (np. czołgów, ciągników, koparek) albo samochodów osobowych. Określenie samochodowa może być mylące jako zbyt szerokie pod względem znaczenia, gdyż obejmuje również przyczepy samochodów osobowych.

$\mathrm{W}$ innym znaczeniu трейлер to zwiastun (filmowy, telewizyjny). Słownik wydany w 2004 roku mógł tego znaczenia jeszcze nie odnotowywać, ale w słownikach nowszych powinno się ono znaleźć.

3) Dyrektywa wyboru w języku rosyjskim

вона [-ны] (денежная единица) won 
Sposób formułowania dyrektywy wyboru jest niejednolity — od jednosłownych i kilkusłownych określeń, poprzez podawanie przykładów użycia загашшник [-ка] (разг.: укромное место для хранения, напр. денег) schowek, aż po rozbudowane definicје манишка [-шки; род. мн. -шек] (нагрудник, надеваемый под жакет вместо блузки) przodzik

4) Nawiasowa wskazówka interpretacyjna w języku polskim, np.:

мозоль [-ли ж] odcisk (nagniotek)

резерват [-та] rezerwat (dla ludzi)

Kryteria wyboru użycia konkretnego rodzaju instrukcji są mało przejrzyste, a sposób formułowania wskazówek interpretacyjnych dość zróżnicowany, np.:

зубрйла [-лы $м, ж]$ kujon (uczeń, uczennica; student, studentka)

судно сосуд [-на; судна, -ден, -днам] basen (naczynie do załatwiania potrzeb fizjologicznych)

миропомазание [-ния] bierzmowanie (symboliczne namaszczenie olejem świętym na znak przyjęcia do wspólnoty chrześcijańskiej, następujące w kościele prawosławnym bezpośrednio po (chrzcie $)^{25}$

5) łączenie wyżej wymienionych metod, np.:

обелитть [-л므, -лишьь; -лённый, -лён, -лена] (снять подозрения) wybielić (oczyścić, np. z zarzutów)

лимонка [-нки; род. мн. -нок] (разг.: граната) granat (pocisk kształtem przypominajacy cytryne)

Wymienione rozwiązania są powielane w przypadku haseł wielopunktowych, np.:

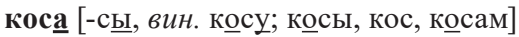

1. (причёска) warkocz

2. (орудие) kosa

3. (Mыс) mierzeja

Wyodrębnienie poszczególnych znaczeń jest w danym przypadku niezbędne, nawiasowa dyrektywa wybory w tym konkretnym przypadku wystarcza do poprawnej identyfikacji poszczególnych znaczeń leksemu wyjściowego i ich polskich ekwiwalentów. Jednak wartość tego i podobnych artykułów hasłowych byłaby znacznie większa, gdyby do każdego podpunktu dodać egzemplifikację materiałową (najlepiej w postaci frazemów). Wówczas hasło mogłoby mieć następujący kształt:

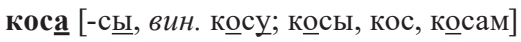

1. (причёска) warkocz

заплетать косу — zaplatać warkocz

2. (орудие) kosa

точйть косуу — ostrzyć kosę

нашла коса на каменнь — trafiła kosa na kamień

25 Wskazówka interpretacyjna w tym haśle przybiera formę artykułu encyklopedycznego. 
3. $($ мыс $)$ mierzeja

Балтийская коса ${ }^{26}$ - Mierzeja Wiślana.

Nowoczesny słownik przekładowy musi prezentować w sposób możliwie pełny przekładowe relacje międzyjęzykowe między jednostkami polisemicznymi, co oznacza praktyczną realizację postulatu opracowywania nowego słownika nie tyle wszerz, co w głąb. Przy takim założeniu kolejny słownik przekładowy może zawierać zbliżoną liczbę haseł jako tradycyjną miarę objętości słownika, ale uwzględniających znacznie większą liczbę znaczeń leksemów wyjściowych, w tym potocznych, pospolitych, wulgarnych, nowych, metaforycznych. Jednocześnie lepsze opracowanie w głąb należy rozumieć jako możliwie szerokie zastosowanie uwag nawiasowych w odniesieniu do poszczególnych znaczeń polisemu jako użytecznej instrukcji stosowania odpowiednika w praktyce translatorycznej, lecz także powrót do tradycyjnego wykorzystania kwalifikatorów i nieporównanie szerszego zastosowania przykładów użycia, w tym frazemów. Te ostatnie w wielu przypadkach mogą z powodzeniem zastępować uwagi nawiasowe oraz różnicować poszczególne znaczenia.

Słownik przekładowy, jak sama nazwa wskazuje, powinien umożliwiać/ ułatwiać proces tłumaczenia. Zgodnie z modelem procesu translatorycznego proponowanym przez francuską szkołę tłumaczy ów proces składa się z trzech faz: rozumienia, dewerbalizacji i reekspresji ${ }^{27}$. Przy tradycyjnej lemmizacji, czyli uwzględnianiu w zasadzie tylko znaczeń/znaczenia denotatywnego już pierwszy etap rozumienia tekstu wyjściowego podczas posiłkowania się słownikiem przekładowym może ulec zaburzeniom - poprawna interpretacja (zrozumienie tekstu w sposób, w jaki pojmuje go adresat, czyli przeciętny członek danej wspólnoty komunikacyjnej, często wymaga znajomości kompleksowego znaczenia jednostek wyjściowych, a więc całokształtu konotacyjnego, typowych kontekstów użycia oraz zapasów poznawczych, do których w świadomości rodzimych użytkowników określonego języka odwołują się konkretne leksemy). Niezależnie od tego, czy do oznaczenia takich kompleksowych jednostek będziemy stosować rosyjski termin koncept, czy np. pojęcie kulturemu, bez uwzględnienia tak rozumianych znaczeń i próby ich ekwiwalentyzacji trudno mówić o słowniku rzeczywiście odpowiadającym wymogom tłumacza. Spełnienie oczekiwań tłumacza oznacza konieczność tworzenia kompleksowych, hybrydowych, a więc mieszanego typu słowników przekładowych, które łączą w sobie elementy słownika dwujęzycznego i różnego rodzaju słowników objaśniających obydwóch języków ze szczególnym uwzględnieniem warstwy konotacyjnej oraz frazematyki jako podstawowego budulca wypowiedzi. Zgadzając się co do istoty z poglądem Anny Bednarczyk:

26 W słowniku PWN nazwy własne są podawane obok nazw pospolitych, co jest rozwiązaniem ze wszech miar słusznym. Nic nie stoi na przeszkodzie, aby w większym stopniu prezentować wyrażenia odonomastyczne $\mathrm{i}$ inne frazemy $\mathrm{z}$ komponentem antroponimicznym lub toponimicznym w charakterze materiału ilustracyjnego.

27 U. Dąmbska-Prokop, O tlumaczeniu źle i dobrze, Kraków 2012, s. 28. 
słowniki dwujęzyczne nie są w rzeczywistości słownikami tłumaczeniowymi, ponieważ mimo wymieniania tłumaczy jako ich głównych użytkowników nie są, jak się wydaje, skierowane do tłumaczy literatury. Stąd np. brak w hasłach rozszerzeń semantycznych. Dotyczy to przede wszystkim nieobecności w hasłach wielu znaczeń i użyć przenośnych, jak również potocznych czy wulgarnych, których tłumacz nie znajdzie także w słownikach specjalnych ${ }^{28}$,

należy dodać, że całą powyższą wypowiedź trzeba odnosić do tłumacza w ogóle: z problemem warstwy konotacyjnej, eksplikacji informacji implicytnych, użyć metaforycznych, odwołań kulturowych i aluzji erudycyjnych spotyka się w swojej praktyce też tłumacz tekstów prasowych, publicystycznych, audiowizualnych, tekstów przemówień, reklamowych, marketingowych i wielu innych.

Postęp technologiczny stwarza wreszcie możliwości opracowywania słowników elektronicznych w trybie online, których nie ograniczają dwie tradycyjne bolączki leksykografa — objętość (tu jest ona niemalże nieograniczona) i czas (zmiany i uzupełnienia w takich słownikach można wprowadzać na bieżąco). Nie bez znaczenia jest swoiste „sprzężenie zwrotne” - autorzy mogą na bieżąco zapoznawać się z komentarzami użytkowników i otrzymywać propozycję zmian. Za wzorcowe rozwiązania jednojęzyczne uważam Wielki słownik języka polskiego ${ }^{29}$ oraz słownik skrótów i abrewiatur języka rosyjskiego www.sokr.ru.

Ten ostatni zawiera aktualnie 147 tysięcy jednostek ${ }^{30} \mathrm{i}$ jest stale rozszerzany. Każdy użytkownik może wysłać swoją propozycję nowego hasła, podhasła, ale o jej ewentualnym uwzględnieniu decydują redaktorzy słownika. Nie znam szybszego i bardziej efektywnego sposobu rozszerzania siatki nowoczesnych słowników online i sądzę, że może on być stosowany przy opracowywaniu nowoczesnych słowników przekładowych.

\section{Bibliografia}

\section{Słowniki}

Hessen D., Stypuła R., Wielki słownik polsko-rosyjski, t. 1-2, wyd. 5, Warszawa 1998.

Mirowicz A., Dulewiczowa I., Grek-Pabisowa I., Maryniakowa I., Wielki stownik rosyjsko-polski, t. 1-2, wyd. 6, Moskwa-Warszawa 1999.

SK: Новейший большой толковый словарь русского языка, red. С.А. Кузнецова, Sankt Petersburg 2008.

Słownik PWN: Wielki słownik rosyjsko-polski z kluczem polsko-rosyjskim, red. J. Wawrzyńczyk, Warszawa 2004.

USJP: Uniwersalny stownik języka polskiego, red. S. Dubisz, Warszawa 2003, CD-ROM.

Wielki słownik języka polskiego, www.wsjp.pl.

WSJP: Wspótczesny słownik języka polskiego, red. B. Dunaj, Warszawa 1999, t. 1-2.

28 A. Bednarczyk, Wybory translatorskie, modyfikacje tekstu literackiego w przekładzie i kontekst asocjacyjny, Łask 2005, s. 99.

29 Wielki słownik języka polskiego, www.wsjp.pl (dostęp: 8.12.2015).

30 www.sokr.ru (dostęp: 8.12.2015). 


\section{Literatura}

Bartwicka H., Krytycznie o sposobie prezentacji leksyki potocznej w Wielkim stowniku polsko-rosyjskim, [w:] Wspótczesny język polski i rosyjski. Konfrontacja przekładowa, red. A. Bogusławski, J. Mędelska, Warszawa 1997, s. 127-145.

Bartwicka H., Mędelska J., Wawrzyńczyk J., Glosy do Wielkiego słownika polsko-rosyjskiego Dymitra Hessena i Ryszarda Styputy, Bydgoszcz 1983.

Bednarczyk A., Wybory translatorskie, modyfikacje tekstu literackiego w przekładzie i kontekst asocjacyjny, Łask 2005.

Dąmbska-Prokop U., O tłumaczeniu źle i dobrze, Kraków 2012.

Gasek B., Odtwarzalne wielowyrazowce w rosyjsko-polskiej leksykografii przekładowej, [w:] Stowo, tekst, czas 12: frazeologia w idiolekcie i systemach języków stowiańskich : w 200. rocznice urodzin Tarasa Szewczenki, t. 1, red. M. Aleksiejenko et al., Szczecin-Greifswald 2014.

Polański K., Polisemia, [w:] Encyklopedia językoznawstwa ogólnego, red. K. Polański, wyd. 2, Wrocław 1999, s. 447.

Wawrzyńczyk J., Aktualne problemy leksykografii polsko-rosyjskiej (Część I), „Przegląd Rusycystyczny" 1984, nr 3.

Wawrzyńczyk J., Aktualne problemy leksykografii polsko-rosyjskiej (Część II), „Przegląd Rusycystyczny" 1984, $\mathrm{nr} 4$.

Wawrzyńczyk J., Język rosyjski w słownikach polsko-rosyjskich powojennego czterdziestolecia, [w:] Z aktualnych studiów rusycystycznych. Językoznawstwo i glottodydaktyka, Olsztyn 1987.

Wawrzyńczyk J., Nowoczesność w polsko-rosyjskiej leksykografii przektadowej (Uwagi o pracy: A. Bogusławski, Ilustrowany stownik rosyjsko-polski i polsko-rosyjski, Warszawa 1978, ss. 1179, „Przegląd Humanistyczny” 1980, nr 4.

Wawrzyńczyk J., O rozwoju leksykografii rosyjsko-polskiej, „Przegląd Rusycystyczny” 1992, nr 3-4.

Wawrzyńczyk J., O tłumaczeniu przymiotników w Wielkim słowniku polsko-rosyjskim, „Przegląd Rusycystyczny" 1983, nr 2.

Wawrzyńczyk J., Wyrazy i zwroty związane z życiem religijnym w ,wielkiej” leksykografii rosyjsko-polskiej, „Acta Polono-Ruthenica” 1997, t. 2.

Wawrzyńczyk J., Blaski i cienie translatosfery, [w:] Na tropach translatów. W poszukiwaniu odpowiedników przekładowych, red. W. Chlebda, Opole 2011.

Wojan K., Rosyjskie leksemy homonimiczne w teorii językoznawczej i praktyce leksykograficznej, Gdańsk 2011.

Wojan K., Wstęp do badań wieloznaczności leksemów w ujęciu kontrastywnym, Gdańsk 2010.

Wstęp, [w:] Wielki słownik rosyjsko-polski z kluczem polsko-rosyjskim, red. J. Wawrzyńczyk, Warszawa 2004.

Бархударов Л.С., Язык и перевод (Вопросы общей и частной теории перевода), Moskwa 1975.

Будагов P.А., Сравнительно-семасиологические исследования (романские языки), Moskwa 1963.

Чернышева М.И., Параметры лексикографической критики, [w:] Слово и словарь. Vocabulum et vocabularium. Сборник научных трудов по лексикографии, wyd. 12, Charkow-Klagenfurt 2011, s. 7-10. 


\section{Polysemy as the problem of translational russian-polish lexicography}

\section{Summary}

The article discusses the problem of polysemy in translation of Russian-Polish dictionary. Critical analysis was conducted on the resources included in The Great Russian-Polish Dictionary edited by "Wydawnictwo PWN". Inaccuracies and mistakes found in dictionary entries allow us to formulate some conclusions about principles for compiling modern Russian-Polish dictionary, which meets translator's expectations.

Keywords: lexicographical criticism, translation Russian-Polish dictionary, polysemy, dictionary equivalents, fixed expressions.

\section{Полисемия как проблема русско-польской переводной лексикографии}

\section{Резюме}

В настоящей статье рассматривается проблема презентации полисемии в большом русско-польском переводном словаре. В ходе анализа Большого русско-польского словаря под редакцией Яна Вавжинчика были выявлены ошибки и недочёты в построении отдельных статей, а также - сделаны выводы насчёт принципов составления современного русско-польского словаря, соответствующего требованиям переводчика.

Ключевые слова: лексикографическая критика, русско-польский переводной словарь, полисемия, словарные соответствия, фраземы. 